\title{
DYNAMICS OF CATTLE FATTENING INDUSTRY IN INDONESIA
}

\author{
Giyono $^{*}$, , Arief Daryanto**), and Dikky Indrawan*) \\ *) School of Business, IPB University \\ Jl. Pajajaran, Bogor 16151, Indonesia \\ **) Department of Economics, Faculty of Economics and Management, IPB University \\ Jl. Agatis, Campus of IPB Darmaga Bogor 16680, Indonesia
}

\begin{abstract}
The cattle fattening industry faces challenges from external factors, especially macroeconomic conditions and industry challenges with the increasing beef substitution imports to replace fresh beef. This research aimed to analyze the dynamics of cattle fattening industry in Indonesia. Porter's Five Forces analysis was conducted to see the mapping of competitions in the cattle fattening industry. PESTEL analysis was conducted to see external factors that affected live cattle imports in Indonesia. Cointegration and Error Correction Model analysis was conducted to see important and influencing factors of live cattle imports in Indonesia as the dependent variables and exchange rates, Gross Domestic Product, beef imports, beef offal imports and buffalo meat imports as the independent variables. This research used time series data based on the 2011-2019 data obtained from the Central Statistics Agency, the Ministry of Agriculture and Bank Indonesia. The results of Porter's Five Forces analysis showed high competition in the cattle fattening industry with the threat of substitute products, which was the factor that fully needed a response with the right strategy by the cattle fattening industry. The results of PESTEL analysis showed that external factors had a high effect on the cattle fattening industry, with the most important things that needed to be considered based on conditions, influences on the industry and level of importance including the factors of the development of animal feed technology, exchange rate fluctuation and national economic growth. The results of the Cointegration and Error Correction Model analysis showed that the factors that were important and affected live cattle imports in Indonesia included exchange rates, beef imports and buffalo meat imports.
\end{abstract}

Keywords: beef, buffalo meat, error correction model, exchange rate, live cattle

\begin{abstract}
Abstrak: Industri penggemukan sapi menghadapi tantangan dari faktor eksternal terutama kondisi makroekonomi dan tantangan industri dengan meningkatnya importasi barang substitusi yang masuk menggantikan daging sapi segar. Penelitian ini bertujuan untuk menganalisis dinamika industri penggemukan sapi di Indonesia. Analisis Porter's Five Forces dilakukan untuk melihat peta persaingan di industri penggemukan sapi. Analisis PESTEL dilakukan untuk melihat faktor eksternal yang mempengaruhi impor sapi hidup di Indonesia. Analisis Kointegrasi dan Error Correction Model dilakukan untuk melihat faktor yang penting dan mempengaruhi impor sapi hidup di Indonesia sebagai variabel terikat dan variabel kurs, Produk Domestik Bruto, impor daging sapi, impor jeroan sapi dan impor daging kerbau sebagai variabel bebas, dengan menggunakan data deret waktu berdasarkan tahun 2011-2019 dan data diperoleh dari Badan Pusat Statistik, Kementerian Pertanian dan Bank Indonesia. Hasil analisis Porter's Five Forces menunjukkan bahwa terjadi persaingan yang tinggi di lingkungan industri penggemukan sapi dengan ancaman produk substitusi merupakan faktor yang paling perlu mendapatkan respon dan disikapi dengan strategi yang tepat oleh industri penggemukan sapi. Hasil analisis PESTEL menunjukkan bahwa faktor eksternal memiliki pengaruh yang tinggi terhadap industri penggemukan sapi, dengan hal yang paling perlu diperhatikan berdasarkan kondisi, pengaruh terhadap industri dan tingkat kepentingannya secara berturut-turut adalah faktor perkembangan tehnologi pakan ternak, fluktuasi nilai tukar (kurs) dan pertumbuhan ekonomi nasional. Hasil analisis Kointegrasi dan Error Correction Model menunjukkan bahwa faktor yang penting dan mempengaruhi impor sapi hidup di Indonesia adalah kurs, impor daging sapi dan impor daging kerbau.
\end{abstract}

Kata kunci: sapi hidup, daging sapi, daging kerbau, kurs, error correction model

\footnotetext{
${ }^{1}$ Corresponding author:

Email: giyonowmp@yahoo.com
} 


\section{INTRODUCTION}

The demand for animal food products in Indonesia has increased in recent years in line with the economic development, improvements in education levels, and changes in lifestyle that occur in the society. With the increasing population and improvement in the standard of living of the Indonesian people, this will certainly encourage changes in the fulfillment of food needs which will gradually change towards the consumption of animal protein. The increase in demand for meat has not been matched by domestic meat production. In fact, the deficit between supply and demand is always increasing. Meat consumption is projected to reach $3.36 \mathrm{~kg} / \mathrm{capita} /$ year in 2020 in line with the population growth, increased public income, and animal protein consumption (Agus and Widi, 2018).

Domestic beef production is not sufficient for national needs, even though meeting the meat national demand is a priority for national food security. The level of productivity and competitiveness of the domestic cattle fattening industry is still low so that it has not been able to achieve meat self-sufficiency in the short term (Wanti, 2013). Projections of total beef production and consumption in the period of 2014-2024 can be seen in Table 1.

To meet the shortage of the meat national demand, the government has implemented an import policy through imports of cattle, beef, and offal and buffalo meat. This import policy is regulated by the Law and Regulation of the Minister of Agriculture and Regulation of the Minister of Trade. This includes regulations governing the import of buffalo meat as a government effort to meet national needs and to provide meat at a lower price as an effort to stabilize meat prices. Darajat et al. (2018) stated that the presence of frozen meat is required as a complementary commodity due to lack of domestic fresh meat supply. Meanwhile, according to Setiaji et al. (2017), government intervention is required as a solution to control inflation of a commodity. Komalawati et al. (2019) and Handayani (2016) state that the slow response of farmers to the increased demand indicates the importance of live cattle and meat imports can be made into a temporary policy to meet beef demand in the short and medium terms.

The source country for cattle imports until 2019 only came from Australia with the consideration that the system adopted by Indonesia is still a country base in which the import of live cattle can only come from countries free of Foot and Mouth Diseases (FMD). In addition, the consideration of a closer distance is a major factor, even though the government has opened a protocol for imports from other countries such as from Mexico. Australia has an advantage over other countries because it is an FMD-free country geographically close to Indonesia and produces cows that can meet the demand for cattle in Indonesia. Jiuhardi (2016) stated that with this country zone policy, Indonesia has become dependent on the supply from Australia. The total of the Australian cattle population in 2018 according to MLA (2020) was approximately 26.3 million tails, and the country has exported live cattle to Indonesia, Vietnam, China, Israel, Russia, Malaysia, Turkey, Japan, the Philippines and Brunei. The volume and value of Indonesian cattle imports in the period of 2011 - 2019 can be seen in Table 2.

Table 1. Projections of total beef production and consumption in the period of 2014-2024

\begin{tabular}{ccccc}
\hline Year & Production (tons) & Consumption (tons) & Discrepancies (tons) & Fulfillment of Domestic Production (\%) \\
\hline 2014 & $301,251.35$ & $593,516.62$ & $292,265.27$ & 50.76 \\
2015 & $355,979.61$ & $639,857.57$ & $283,877.96$ & 55.63 \\
2016 & $365,056.87$ & $684,884.27$ & $319,827.40$ & 53.30 \\
2017 & $374,134.12$ & $729,910.96$ & $355,776.85$ & 51.26 \\
2018 & $383,211.37$ & $774,937.66$ & $391,726.29$ & 49.45 \\
2019 & $392,288.62$ & $819,964.36$ & $427,675.73$ & 47.84 \\
2020 & $401,365.88$ & $864,991.05$ & $463,625.18$ & 46.40 \\
2021 & $410,443.13$ & $910,017.75$ & $499,574.62$ & 45.10 \\
2022 & $419,520.38$ & $955,044.45$ & $535,524.07$ & 43.93 \\
2023 & $428,597.63$ & $1,000,071.14$ & $571,473.51$ & 43.76 \\
2024 & $437,674.89$ & $1,045,097.84$ & $607,422.95$ & 42.75 \\
\hline
\end{tabular}

Source: Agus et al. 2014 
Table 2. Volume and value of Indonesian imports in the period of $2011-2019$

\begin{tabular}{ccc}
\hline Year & \multicolumn{2}{c}{ Cattle Import } \\
\cline { 2 - 3 } & Volume (ton) & Value (000 US\$) \\
\hline 2011 & 118,921 & 321,001 \\
2012 & 78,906 & 218,533 \\
2013 & 130,021 & 338,399 \\
2015 & 246,834 & 682,098 \\
2016 & 197,604 & 545,576 \\
2017 & 195,764 & 601,463 \\
2018 & 168,589 & 520,142 \\
2019 & 204,683 & 570,847 \\
\end{tabular}

Source: BPS, 2020

The source of meeting the demand for meat is also met from the imports of beef and beef offal. The imports of beef and beef offal based on BPS (2020) come from Australia, New Zealand, the United States, Japan, Canada, Spain and from countries that have recently opened their import protocols including from Brazil. Since 2016, the Government of Indonesia has adopted a policy of importing buffalo meat from India to meet the meat national demand and to stabilize prices. The volume and value of imports of Indonesian beef, beef offal, and buffalo meat in the period of 2011 - 2019 can be seen in Table 3 .

The cattle fattening industry plays an important role in assisting the government in fulfilling the meat national demand through the provision of live cattle ready for slaughtering, and it is hoped that it will provide a positive multiplier effect on other economic sectors. According to Priyarsono et al. (2005), the livestock sub-sector has a multiplier coefficient of 7.23 for gross output, 4.94 for the level of linkage, 2.14 for added value and 1.79 for household income, indicating that the livestock sub-sector has the potential to be a new source of growth in the agricultural sector.

The result of the IRSA research (2009) concluded that the livestock sub-sector, especially beef, has significant linkages with other industrial sectors of meat industry, offal and the like (code 49) related to 37 upstream sectors and 29 downstream sectors, while the processed meat industry and durability (code 50) relates to 37 upstream sectors and 17 downstream sectors, indicating that if the domestic beef cattle industry is disrupted, at least 66 upstream sectors and 54 other sectors will be disrupted either in terms of marketing outputs or obtaining inputs. The research result by IRSA (2009) also states that the effect of industrial changes on the total national output (output multiplier number) of the meat, offal industry and the like (code 49) reached 2.35 or was in the first rank of 175 sectors, while the processed and preserved meat industry output multiplier number (code 50) reached 1.89 or ranked 29 out of 175 sectors. The output multiplier figure is reasonably high because the meat industry requires input from other sectors, such as rice, maize, forage, concentrate feed, and medicine and this demand will induce the sectors that become these inputs.

The economic impact from cattle is the added value of inputs used for fattening the cattle as well as for labor and feed materials, and when viewed from the aspect of beef cattle cultivation, the most benefit felt from this business is the increase in body weight of cows cultivated by breeders or fattening companies (feedlotters), while on the supply side, it will have an impact on increasing meat production which will result in a decrease in the number of slaughtered cattle, and this business also brings benefits to the residents around the area of the company engaged in cattle farming and agriculture and can create jobs which will directly improve the region's economy (Tawaf, 2007).

Tawaf (2007) states that the imported cattle business is able to help small entrepreneurs and farmers to get added value by providing a fairly wide multiplier effect, including the business of skin, bones, blood, fats and fertilizers produced by imported cattle, as well as a number of labor, which can be absorbed, so that if we look at its role, the business is able to help control the possibility of depletion of the local livestock population, has a double effect on the lives of rural communities, provides cheap credit facilities for traders 
and plasma breeders and provision of animal protein for the community. Furthermore, Tawaf (2007) also states that beef cattle fattening business provides other benefits, including cow dung which can be processed into organic fertilizer and biogas. Besides, agricultural waste can also be used as a source of feed for the beef cattle fattening industry, such as straws/hays, brown leather processing waste, coffee skin waste, and others that will directly increase income in the agricultural sector, so that this business has a multiplier effect on the agricultural sector.

Several studies examined the effect of macroeconomic variables and substituted goods variables on imports. Richart and Meydianawati (2014) state that imports are influenced by exchange rates because in conducting international trade each country uses different currencies, and exchange rates act as a facilitator to compare the values of currencies among the countries. Agus and Ayuningsasi (2016), Elif and Oksan (2014), Amaliah and Fahmi (2007) and Udiyana et al. (2017) in their research also state that imports are influenced by exchange rates and by the country's Gross Domestic Product (GDP) because it will increase people's purchasing power (Larasati and Sulasmiyati 2018). Amaliah and Fahmi (2007) and Ayuwangi and Widyastutik (2013) in their research also state that Gross Domestic Product (GDP) affects imports because it will increase people's purchasing power. Meanwhile,
Agus and Ayuningsasi (2016) explain that beef imports have an effect on live cattle imports to Indonesia.

Based on the business process of the fattening industry, imports of beef, offal and buffalo meat are felt to have a less multiplier effect than live cattle imports. Imports of live cattle that go through a fattening process for 4 months can have a more positive multiplier effect on the absorptions of labor and raw materials, fertilizer provision, drive of the cattle slaughtering industry, fulfillment of demand for fresh meat in traditional markets, drive of the leather processing industry as well as derivatives of beef processing industry. The high imports of beef, beef offal and buffalo meat will eliminate the positive multiplier effects caused by live cattle imports.

The cattle fattening industry faces challenges from external factors, especially the macroeconomic conditions and industry challenges with the increasing imports of substituted goods that enter the country and are able to replace fresh beef. Based on this, it is necessary to investigate the factors that influence live cattle imports to Indonesia with the following objectives: (1) Analysing the industrial environment in the cattle fattening industry; (2) Analysing external factors affecting cattle imports in Indonesia, and (3) Analysing the factors that influence cattle imports in Indonesia, both in the short and long terms.

Table 3, Volumes and values of Indonesian imports of beef, beef offal and buffalo meet in the period of 2011 2019

\begin{tabular}{lcccccc}
\hline & \multicolumn{2}{c}{ Beef Import } & \multicolumn{2}{c}{ Beef Offal Import } & \multicolumn{2}{c}{ Buffalo Meat Import } \\
\cline { 2 - 7 } Year & Volume (ton) & $\begin{array}{c}\text { Value } \\
\text { (000 US\$) }\end{array}$ & Volume (ton) & $\begin{array}{c}\text { Value } \\
(\text { 000 US\$) }\end{array}$ & Volume (ton) & $\begin{array}{c}\text { Value } \\
(000 \text { US\$) }\end{array}$ \\
\hline 2011 & 65,022 & 234,266 & 37,828 & 87,154 & - & - \\
2012 & 33,506 & 139,214 & 6,834 & 16,792 & - & - \\
2013 & 45,503 & 211,232 & 9,352 & 27,381 & - & - \\
2014 & 74,648 & 346,812 & 30,284 & 85,736 & - & - \\
2015 & 48,216 & 226,513 & 2,473 & 14,082 & 79,524 & 141,463 \\
2016 & 74,945 & 341,907 & 32,203 & 75,460 & 39,192 & 166,102 \\
2017 & 70,584 & 300,760 & 44,421 & 105,167 & 45,634 & 283,651 \\
2018 & 81,012 & 317,166 & 46,781 & 106,913 & 79,634 \\
2019 & 103,377 & 380,397 & 64,904 & 139,609 & 93,970 & 309,849 \\
\hline
\end{tabular}

Source: BPS (2020) and Ministry of Agriculture (2020) 


\section{METHODS}

The picture of the imported cattle fattening industry was obtained from the result of the industrial analysis (Porter's 5 Force Model) based on the variables of the competition among similar companies, threats of new entrants and substitute products, bargaining power of buyers and suppliers (Porter, 2006; Foris and Mustamu, 2015; Viali et al. 2018). Analysis of external factors that affect cattle imports using PESTEL Analysis based on the Political, Economical, Sociocultural, Technical, Ecological, and Legal variables (Hunger and Wheelen, 2011). Analysis on the factors that influence cattle imports was conducted using macroeconomic variables derived from PESTEL Analysis including the exchange rate and GDP variables, and threat of substitute products derived from Porter's 5 Force Model industry analysis including imports of beef, beef offal, and buffalo meat. This research used the secondary data (time series) of quantitative data with 9 years of observation from 2011 to 2019 . The research objects included monthly data on cattle imports, exchange rates, GDP, beef imports, beef offal imports and buffalo meat imports obtained from several sources of the Central Statistics Agency (BPS, 2020), the Ministry of Agriculture (Kemtan, 2020) and Bank Indonesia (BI, 2020).

\section{Industrial Analysis (Porter's 5 Forces Model)}

The industrial analysis (Porters 5 Forces Model) was conducted to describe the conditions of the imported cattle fattening industry. The research data included qualitative data obtained from the questionnaire filled out by 3 people selected purposely (purposive sampling) with a professional background in the field of imported cattle fattening. The questionnaire contained 5 Porter's 5 Force Model variables, and each statement was given an assessment on a Likert scale to determine the mapping of the competitive strengths of the cattle fattening industry. Statements compiled by the researchers were based on the data observations (internet, reports, government policies) and literature reviews to obtain various data and information that can be used as a theoretical basis and references in processing data by reading, researching and reviewing the literature, journals, and previous studies related to the problem of this research. The Likert scale was based on the level of competition, magnitude of the threat and magnitude of the strength of the variables toward the cattle fattening industry on a scale of $1=$ Very Low, $2=$ Low, $3=$ Medium, $4=$ High and $5=$
Very High. The method of processing data from the results of filling out questionnaires by experts used the Delphi technique with the stages of determining the weight, value, weighted score, interpretation criteria and industrial competition maps based on the variable weighted score. The Delphi technique was used to process the data from the questionnaire by determining the weight, value, weighted score, interpretation criteria, and industry competition mapping based on weighted score variable.

\section{Analysis on the External Factors (PESTEL Analysis)}

The PESTEL Analysis was conducted to analyze external factors that influenced cattle imports in Indonesia. The research used qualitative data obtained from the questionnaire filled out by 3 people selected purposely (purposive sampling) with a professional background in the field of imported cattle fattening. The questionnaire contained statements which were given an assessment on a Likert scale to determine the influences and importance level on the cattle fattening industry. The statements compiled by the researchers were based on data observations (internet, reports, and government policies) and literature reviews to obtain various data and information that could be used as a theoretical basis and reference in processing data by reading, researching, and reviewing literature, journals, and previous studies related to the problem of the research. The Likert scale was based on the magnitude of the influence on the cattle fattening industry: $1=$ Very Low, 2 = Low, 3 = Medium, $4=$ High and 5 = Very High. The data from the results of the questionnaire were processed used the Delphi technique in determining the weight, values, weighted scores, interpretation criteria and importance level based on the total weighted score of each variable.

\section{Quantitative Analysis}

Quantitative analysis of the estimator model was used to analyze the factors that influenced cattle imports in Indonesia, using multiple linear regression analysis with the Ordinary Least Squares (OLS) method through the cointegration test approach and the Error Correction Model (ECM) test using the Eviews 10 software (Muhammad, 2014; Laksono, 2016). The long-run regression equation is as follows:

$$
\mathrm{Y}_{\mathrm{t}}=\beta_{0}+\beta_{1} \mathrm{X} 1_{\mathrm{t}}+\beta_{2} \mathrm{X} 2_{\mathrm{t}}+\beta_{3} \mathrm{X} 3_{\mathrm{t}}+\beta_{4} \mathrm{X} 4_{\mathrm{t}}+\beta_{5} \mathrm{X} 5_{\mathrm{t}}+\mathrm{e}_{\mathrm{t}}
$$


Description: $\beta=$ Konstanta, $\hat{Y}=$ Live Cattle Import (ton), $\mathrm{X} 1=$ Exchange rates in US Dollar $(\mathrm{Rp} / \mathrm{USD})$, $\mathrm{X} 2=$ Gross Domestic Product (billion rupiahs), X3 = Beef Import (ton), X4 = Beef Offal Import (ton), X5 = Buffalo Beef Import (ton), e $=$ Standard Error.

The short-run regression equation at the 1 st difference is as follows:

$$
\begin{aligned}
\Delta \mathrm{Y}_{\mathrm{t}}= & \alpha_{0}+\alpha_{1} \Delta \mathrm{X} 1_{\mathrm{t}}+\alpha_{2} \Delta \mathrm{X} 2_{\mathrm{t}}+\alpha_{3} \Delta \mathrm{XX} 3_{\mathrm{t}}+\alpha_{4} \Delta \mathrm{X} 4_{\mathrm{t}}+ \\
& \alpha_{5} \Delta \mathrm{X} 5_{\mathrm{t}}+\gamma \mathrm{ECT} T_{\mathrm{t}-1}+v_{\mathrm{t}} .
\end{aligned}
$$

Description: $\alpha=$ Konstanta, $\hat{Y}=$ Live Cattle Import (ton), $\mathrm{X} 1=$ Exchange rates in US Dollar (Rp/USD), $\mathrm{X} 2=\mathrm{PDB}$ (billion rupiahs), $\mathrm{X} 3=$ Exchange rates in US Dollar (ton), X4 = Beef Offal Import (ton), X5 $=$ Buffalo Beef Import (ton), ECT $=$ Error Correction Term, $\gamma=$ Speed of adjusment (residual speed/error (e) in the previous period to correct the change of $Y$ variable toward a balance in the following period, and $v=$ error.

\section{Hypothesis}

The hypotheses of this research are as follows: (1) There is high competition in the cattle fattening industry with the threat of substitute goods being the most important variable, (2) the external factors have a very strong influence on the cattle fattening industry, and (3) the variables of exchange rates and imports of beef and buffalo meat are factors influencing the cattle imports by Indonesia.

\section{Theoretical Framework}

To determine the description of the cattle fattening industry, an industrial analysis was carried out (Porters 5 Forces Model). Furthermore, analysis on external factors (PESTEL Analysis) was carried out to identify factors that affect cattle imports in Indonesia. Quantitative analysis of the estimator model was used to analyze the factors that influence cattle imports in Indonesia using the macroeconomic variables derived from PESTEL Analysis including the exchange rate and GDP, and the variable of the derivative product threat from Porter's 5 Force Model industrial analysis including imports of beef, beef offal and buffalo meat. Theoretical framework in Figure 1.

\section{RESULTS}

\section{Overview on Imported Cattle Fattening Industry}

Based on the result of industrial analysis with the Porter's 5 Forces Model, there is a high competition in the cattle fattening industry, a high threat of new comers, a high threat of substituted products, high power of bargaining position of the buyers and high bargaining power of the suppliers (Table 4). The sequence of mapping the power of competition includes the threat of substitute products (total weighted score of 3.89), competition among similar companies (total weighted score of 3.65), bargaining power of buyers (total weighted score of 3.49), bargaining power of suppliers (total weighted score of 3.47) and threat of new comers (total weighted score 3.46). The threat of substituted products is the factor that most needs to get a response and be addressed with the right strategy by the cattle fattening industry because it has the highest weighted score.

\section{External Factors Affecting Cattle Imports}

Based on the results of PESTEL analysis, the external factors including the political, economic, sociocultural, technological, ecological and legal factors had a high influence on the cattle fattening industry indicated by a total weighted score of 3.87 (Table 5). The things that need to be considered the most based on the conditions, influence on the industry, and level of importance included the factors of the animal feed technology development, exchange rate fluctuations, and national economic growth.

The cattle fattening industry places the factors, especially the animal feed technology factor, at the greatest weighted score $(0.34)$ as a very important factor. This is because the cattle fattening industry in its business process has to go through a fattening process for 4 months and requires high quality animal feed to obtain high productivity rates. According to the research of Abdulla et al. (2016), animal feed efficiency is one of the factors in livestock production management to support the achievement of national beef self-sufficiency. 
Table 4. Mapping of the competitive strengths of the industrial environment

\begin{tabular}{lcc}
\hline Porter's Five Force & Total of Weighted Score & Criteria \\
\hline Competitions among similar companies & 3.65 & High Competition \\
Threat of New Comers & 3.46 & High Threat \\
Threat of Substituted Products & 3.89 & High Threat \\
Strength of Bargaining Power of the Buyers & 3.49 & High Strength \\
Strength of Bargaining Power of the Suppliers & 3.47 & High Strength \\
\hline
\end{tabular}

Table 5. External analysis on the cattle fattening industry

\begin{tabular}{llcc}
\hline Factors & Conditions & $\begin{array}{c}\text { Weighted } \\
\text { Scores }\end{array}$ & $\begin{array}{c}\text { Importance } \\
\text { Level }\end{array}$ \\
\hline Political & Country base system so that Indonesia can only import cattle from FMD-free & 0.29 & 2 \\
& countries & & \\
& Buffalo meat import policy for the purpose of price stabilization & 0.14 & 6 \\
& Beef self-sufficiency policy & 0.25 & 3 \\
Economical & Exchange rate fluctuation & 0.29 & 2 \\
& Inflation conditions & 0.17 & 5 \\
& Gross Domestic Product & 0.17 & 5 \\
& National economic growth & 0.29 & 2 \\
Sosiocultural & Variety of Indonesian beef-based culinary & 0.17 & 5 \\
& Lifestyle of the millennial generation & 0.17 & 5 \\
& Religious Holidays & 0.25 & 3 \\
Technological & Artificial Insemination Technology & 0.14 & 6 \\
& Animal feed technology & 0.34 & 1 \\
& Meat processing technology & 0.25 & 3 \\
Ecological & Farming layout & 0.25 & 3 \\
& Distribution chain & 0.25 & 3 \\
& Import regulations & 0.25 & 3 \\
& Role of the supervisory agency & 0.21 & 4 \\
\hline
\end{tabular}

\section{Factors Affecting Cattle Imports}

The result of the equation estimations of the long and short-terms can be seen in Table 6 .

\section{The Effect of Exchange Rates, Inflation, and Imports of Buffalo, Beef, Beef Offal and Buffalo Beef on Cattle Imports in Indonesia}

Based on the results of the equation estimation of the long-term, the most influential factors on cattle imports included exchange rates (Prob 0.00) and beef imports (Prob 0.01) meanwhile, for the short-term equation, the most influential factors on cattle imports were buffalo meat imports (Prob 0.03) and beef imports (Prob $0.04)$.
The Effect of Exchange Rates on Cattle Imports in Indonesia

The results showed that the exchange rates only partially had a significant effect on cattle imports in Indonesia in the long run and had a positive (directly proportional) relationship with live cattle imports. This result is not in accordance with the theory which states that exchange rate is negatively correlated with imports, but it is possible that in the long run, the increase in the exchange rate will still be responded positively by the cattle fattening industry i.e. by increasing imports due to an increase in national beef demand. Meanwhile, in the short term, the exchange rate partially has no significant effects on cattle imports in Indonesia. 
Table 6. Estimates of long and short run equations

\begin{tabular}{|c|c|c|c|c|}
\hline \multirow{2}{*}{ Variables } & \multicolumn{2}{|c|}{ Long-term } & \multicolumn{2}{|c|}{ Short-term } \\
\hline & Coefficient & Prob & Coefficient & Prob \\
\hline $\mathrm{C}$ & -10.864 .05 & 0.01 & 186.13 & 0.74 \\
\hline Exhange rates & 2.83 & $0.00 *$ & -0.17 & 0.93 \\
\hline GDP & -0.98 & 0.07 & -1.22 & 0.51 \\
\hline Beef Import & 0.96 & $0.01 *$ & 0.67 & $0.04 *$ \\
\hline Beef Offal Import & 0.25 & 0.68 & 0.39 & 0.57 \\
\hline Buffalo Meat Import & 0.02 & 0.87 & 0.33 & $0.03 *$ \\
\hline $\operatorname{Res}(-1)$ & & & -0.99 & 0.00 \\
\hline R-Squared & & 0.39 & & 0.56 \\
\hline F-Statistic & & 13.15 & & 21.39 \\
\hline Prob (F-Statistic) & & 0.00 & & 0.00 \\
\hline
\end{tabular}

The research by Udiyana et al. (2017) shows that the exchange rate individually or partially has a significant effect on export-import. The research by Agus and Ayuningsasi (2016); Amaliah and Fahmi (2007); Ayuwangi and Widyastutik (2013); Elif and Oksan (2014) also state that the US dollar exchange rate has a significant effect on imports. This can be explained because the trade carried out between the two countries, in this case Indonesia and Australia, always uses two different currencies, so it is very dependent on the exchange rate so that it can be a reference for importers to make import decisions, because the weakening of the domestic rupiah exchange rate will make the prices of imported goods higher; as a result, the demand for imported goods will decrease (Prafajarika et al. 2016).

The Effect of Beef Imports on Cattle Imports in Indonesia

The results showed that beef imports partially had a significant effect on cattle imports in Indonesia in the long and short terms. This can be explained because imported meat products and fresh meat products from the slaughter of the fattening industry directly have the same market in traditional markets, processing industries, hotels, restaurants, and catering. This is in accordance with the research from Agus and Ayuningsasi (2016) explaining that imported beef has a significant effect on Australian cattle imports to Indonesia.

The Effect of Buffalo Meat Imports on Cattle Imports in Indonesia

The results showed that in the long term, the partial import of buffalo meat has no significant effects on cattle imports in Indonesia. This is because the import of buffalo meat from India has only been implemented since August 2016 so that it has no real effects on cattle imports. Meanwhile, in the short term, buffalo meat import has a significant effect on cattle imports in Indonesia. This can be explained because after the import of buffalo meat in 2016, there has been a shift in the market where Indian buffalo meat becomes a substitute and fills the market usually only filled by beef. The growths of buffalo meat imports from 2016 to 2019 as much as 39.5 thousand tons, 45.2 thousand tons, 79.6 thousand tons and 93.9 thousand tons respectively show an incredibly high increase, and it is able to enter and be absorbed by the market. According to Elzerman et al. (2011), meat substitution is able to replace meat on condition that it has a similar shape even though the taste and texture are different. This is because although when tasted separately it will have a different taste, but it is not always different when the meat is tasted in the form of processed products.

Meanwhile, according to Apostolidis and McLeay (2016), consumer choices to buy meat products or meat substitutes are influenced by a number of factors such as advertisements, promotions and policy interventions, and by consumer preferences where meat substitute products are strongly influenced by the product familiarity. Buffalo meat imported from India has been able to influence cattle imports and has taken a position as a substitute item within a 4-year period of importation.

\section{Managerial Implications}

This research has the following business implications for imported cattle feedstock based fattening companies: (1) Cattle fattening companies must be able to develop 
a financial strategy with the following aspects to procure the right raw materials when importing by looking at the positions of the purchase price and exchange rates and performing efficient financing; (2) Cattle fattening companies must be able to compete by increasing production, quality and efficiency of the beef fattening process so that the products produced are able to compete with imported beef and buffalo beef; (3) Cattle fattening companies must be able to maintain business continuity by maintaining the established market and the existing distribution channels because if a shift occurs it will require high costs to return to a better position; and (4) cattle fattening companies must be able to compete with substituted goods by increasing efficiency of the supply chain.

The implications of the government policy related to this research include that: (1) the government must have an accurate national database regarding the availability of supply, price and demand which reflects the actual conditions as the basis for determining the regulation of the imports of livestock products; (2) the government must be able to create a competitive healthy climate, to maintain exchange rate, and to prevent inflation that is too high in order to keep the economy growing; (3) the government must organize livestock spatial planning appropriately and prepare logistics infrastructure for efficient distribution of livestock products to accelerate the development of the livestock industry, (4) the government must be able to increase the productivity and competitiveness of breeders with the technology of breeding, fattening, feed and livestock product processing, and (5) the government must be able to embrace all stake holders by issuing appropriate policies so that the cattle fattening industry can play its role in meeting the national demand for beef and is able to drive the national economy through the multiplier effects of the business process during the fattening period.

\section{CONCLUSIONS AND RECOMMENDATIONS}

\section{Conclusions}

The conclusions obtained from this research include that: (1) there is high competition in the cattle fattening industry with the threat of substituted products which becomes the factor that needs to be responded the most and be addressed with the right strategy by the cattle fattening industry; (2) external factors have significant influences on the cattle fattening industry by greatly paying attention at the conditions, influences on industry, and level of importance including the technological development factor of animal feed, exchange rate fluctuations and national economic growth. The cattle fattening industry places the technological factors, especially the animal feed technology, as a very important factor because the cattle fattening industry in its business processes has to go through a fattening process for 4 months and requires high quality animal feed to get high productivity figures; and (3) the factors that are important and influence live cattle imports in Indonesia include exchange rates, beef and buffalo beef imports.

\section{Recommendations}

Recommendations related to the results of this research include that: (1) the cattle fattening industry must increase maintenance efficiency so that they can compete with imported beef, beef offal and buffalo meat; (2) the government needs to increase domestic beef production to reduce imports, and to prioritize policies that still consider the positive effects on the cattle fattening industry to fulfill the national meet demand; (3) the government not only takes policies to increase production and control prices, but also needs to increase the availability and accuracy of data so that policies related to distribution systems, stock mechanisms and price control are more appropriate, and (4) this research has limitations that it: (a) did not include the domestic beef production variable in the research model, (b) did not include government policy variables in the research model, (c) did not examine the social effects of buffalo meat imports on the social economy of the fattening cattle industry, and (e) did not examine the cross elasticity between the number of imported cows demanded against changes in the prices of imported beef, beef offal and buffalo meat; therefore, it is suggested to the following researchers to examine the limitations of this research.

\section{REFERENCES}

Abdulla I, Arshad FM, Bala BK, Bach NL dan Mohammadi S. 2016. Management of beef cattle production in Malaysia: A step forward to sustainability. American Journal of Applied Sciences 13(9): 976-983. https://doi.org/10.3844/ ajassp.2016.976.983. 
Agus A et al. 2014. Road Map Industri Sapi Potong di Indonesia. Yogyakarta: APFINDO dan Fakultas Peternakan Universitas Gadjah Mada.

Agus A, Widi TSM. 2018. Current situation and prospect of beef cattle production in Indonesia - A review. Asian-Australasian Jounal of Animal Sciences 31: 1-8. https://doi.org/10.5713/ ajas.18.0233.

Agus IMD, Ayuningsasi AAK. 2016. Pengaruh kurs, harga dan PDB terhadap impor sapi Australia ke Indonesia. E-Jurnal EP Unud 5(7): 754-777.

Amaliah S, Fahmi I. 2007. Faktor - faktor yang mempengaruhi impor susu Indonesia. Jurnal Manajemen dan Agribisnis 4(2): 91-102.

Apostolidis C, McLeay F. 2016. Should we stop meating like this? Reducing meat consumption through substitution. Food Policy 65(2016): 74-89. https://doi.org/10.1016/j.foodpol.2016.11.002.

Ayuwangi A, Widyastutik. 2013. Pengaruh variabel ekonomi dan non ekonomi terhadap impor Indonesia dari ASEAN+6 melalui moda transportasi laut. Buletin Ilmiah Litbang Perdagangan 7(2): 231-247.

[BI] Bank Indonesia. 2020. Statistik Ekonomi dan Keuangan Indonesia. https://www.bi.go.id.[27 Jan 2020].

[BPS] Biro Pusat Statistik. 2020. Berita Resmi Statistik. https://www.bps.go.id/pressrelease.html. [20 Jun 2020].

[BPS] Biro Pusat Statistik. 2020. Ekspor dan Impor. https://www.bps.go.id/all_newtemplate.php. [27 Jan 2020].

Darajat MY, Komarudin dan Hidayatno A. 2018. Inventory simulation model of frozen-meat for food-safety program. Communications in Science and Technology 3(1): 36-43. https://doi. org/10.21924/cst.3.1.2018.81.

Elif GG, Oksan KA. 2014. The effect of exchange rates on exports and imports of emerging countries. European Scientific Journal 10(13): 128 - 141.

Elzerman JE, Hoek AC, van Boekel MAJS dan Luning PA. 2011. Consumer acceptance and appropriateness of meat substitutes in a meal context. Food Quality and Preference 22(2011): 233-240. https://doi.org/10.1016/j. foodqual.2010.10.006.

Foris PJ, Mustamu RH. 2015. Analisis strategi pada perusahaan plastik dengan Porter Five Forces. Agora 3(1): 736-741.

Handayani S. 2016. Model ekonomi daging sapi di Indonesia. Jurnal Bisnis Tani 2(1): 29-41.
Hunger JD, Wheelen TL. 2011. Essentials of Strategic Management. 5th edition. New Jersey: Pearson Education Inc.

[IRSA] Indonesia Research Strategic Analysis. 2009. Pengaturan Kebijakan Industri Daging Sapi di Indonesia. Jakarta: Indonesia Research Strategic Analysis.

Jiuhardi. 2016. Kajian tentang impor daging sapi di Indonesia. Forum Ekonomi 17(2): 75-91

[Kementan] KementerianPertanian Republik Indonesia. 2020. Basis Data Ekspor-Impor Komoditi Pertanian. http://database.pertanian.go.id/eksim/ index1.asp [6 Jan 2020].

Komalawati, Asmarantaka RW, Nurmalina R dan Hakim DB. 2019. Modeling price volatility and supply response of beef in Indonesia. Tropical Animal Science Journal 42(2): 159-166. https:// doi.org/10.5398/tasj.2019.42.2.159.

Laksono R. 2016. Analisis pengaruh suku bunga, pendapatan nasional dan inflasi terhadap nilai tukar nominal: Pendekatan dengan Cointegration dan Error Correction Model (ECM). Jurnal Riset Akuntansi dan Keuangan 4(1): 911-926. https:// doi.org/10.17509/jrak.v4i1.7715.

Larasati IS, Sulasmiyati S. 2018. Pengaruh inflasi, ekspor, dan tenaga kerja terhadap Produk Domestik Bruto (PDB) (Studi pada Indonesia, Malaysia, Singapura, dan Thailand). Jurnal Administrasi Bisnis 4(1): 8-16.

[MLA] Meat and Livestock Australia. 2020. Statistics Database. http://statistics.mla.com.au/Report/ List. [22 Apr 2020].

Muhammad M. 2014. Kointegrasi dan estimasi ECM pada data time series. Jurnal Konvergensi 4(1): $41-51$.

Porter ME. 2006. HBR's must-reads on strategy. The five competitive forces that shape strategy. Harvard Business Review 23-40.

Prafajarika SW, Yulianto E, Wilopo. 2016. Pengaruh nilai tukar, harga dalam negeri dan harga internasional terhadap volume impor daging sapi Indonesia (Survey volume impor komoditi daging sapi Indonesia tahun 2012 -2014). Jurnal Administrasi Bisnis 34 (1): 65-72.

Priyarsono DS, Daryanto A, Herliana L. 2005. Dapatkah Pertanian Menjadi Mesin Pertumbuhan Ekonomi Indonesia? Analisis Sistem Neraca Sosial Ekonomi. AgroEkonomika 35(1): 37-47.

Richart PSW, Meydianawati LG. 2014. Faktor faktor yang berpengaruh terhadap impor barang konsumsi di Indonesia. E-Jurnal EP UNUD 
3(12): 613-623.

Setiaji B, Susila I, Wahyudi HD. 2017. Supply chain of the beef market in Indonesia. Expert Journal of Business and Management 5(2): 129-135.

Tawaf R. 2007. Perspektif industri penggemukan sapi potong impor (feedlot) di Indonesia. Simposium Kebudayaan Indonesia - Malaysia (SKIM X).

Udiyana IBG, Setyarti T, Astini NNS, Aniyati I. 2017. Fluktuasi nilai kurs dan inflasi pengaruhnya terhadap ekspor impor dan neraca perdagangan
Indonesia tahun 2007-2015. Forum Manajemen 15(1): 76-86.

Viali AF, Rifin A dan Saptono IT. 2018. Strategi pengembanganbisniscargo PT.GarudaIndonesia, Tbk dengan pendekatan business model canvas. Jurnal Aplikasi Bisnis dan Manajemen 4(3): 474 - 485. https://doi.org/10.17358/jabm.4.3.474.

Wanti PIN. 2013. Analisis daya saing industri penggemukan sapi potong lokal di Indonesia [tesis]. Bogor: Institut Pertanian Bogor. 